\title{
From the Octagon to the Courtroom: The Right to Fight, Subaltern, Cosmopolitanism, and Public Interest Litigation as a Tool for Mixed Martial Arts as a Community/Cultural Normative System
}

Sara Gwendolyn Ross

Follow this and additional works at: https://via.library.depaul.edu/jslcp

Part of the Entertainment, Arts, and Sports Law Commons

\section{Recommended Citation}

Sara Gwendolyn Ross, From the Octagon to the Courtroom: The Right to Fight, Subaltern, Cosmopolitanism, and Public Interest Litigation as a Tool for Mixed Martial Arts as a Community/Cultural Normative System, 11 DePaul J. Sports L. \& Contemp. Probs. (2016)

Available at: https://via.library.depaul.edu/jslcp/vol11/iss1/5 


\title{
FROM THE OCTAGON TO THE COURTROOM: THE RIGHT TO FIGHT, SUBALTERN COSMOPOLITANISM, AND PUBLIC INTEREST LITIGATION AS A TOOL FOR MIXED MARTIAL ARTS AS A COMMUNITY/CULTURAL NORMATIVE SYSTEM
}

\author{
Sara Gwendolyn Ross*
}

\begin{abstract}
By training in MMA I entered a community. This was not simply a collection of people looking to increase their fighting skills... [T]he community is comprised of fighters with aspirations of competing professionally, people who have competed in cage fights or martial arts competitions but have no aspirations of money or fame, and hobbyists who train but have no visions of competition. The fights of those who do compete serve as a communal moment for other members. ${ }^{1}$
\end{abstract}

As a new sport, mixed martial arts ("MMA") has grown wildly in popularity. Yet MMA faces hurdles in legitimization and acceptance through legal, regulatory, and political means. While the MMA community has gone to great lengths to change its image, its internal rules, and regulatory framework - and while most American states and Canadian provinces now legally regulate MMA - certain states, such as New York, continue to ban live professional MMA events.

MMA suffers from a lack of scholarship across many disciplines, ${ }^{2}$ including legal scholarship. While the available literature on MMA gradually develops, the minimal legal scholarship related to the matter has concentrated on the practical rather than the theoretical. How-

* Sara Ross is a PhD student and Instructor at Osgoode Hall Law School. She is a member of the Bar of Ontario and holds an LLM from the University of Ottawa. In 2012 she earned her BCL and LLB with a major in Commercial Negotiation and Dispute Resolution from McGill University's Faculty of Law - where she had served as Editor-in-Chief of the McGill Law Journal, Book Review Editor of the McGill International Journal of Sustainability Law and Policy, and VP-Finance of the McGill International Law Society. She would like to thank Professor Ravi Malhotra for his thoughts and encouragement on this work, Professor Angela Cameron for her guidance on legal theory, and Professor Sophie Thériault for her encouragement and advice.

1. Kyle Green, It Hurts So Real: Sensing the Seduction of Mixed Martial Arts, 12:4 Soc. \& Cultural Geography 377, 383 (2011).

2. Dale C. Spencer, Habit(us), Body Techniques and Body Callusing: An Ethnography of Mixed Martial Arts, 15:4 Body \& Society 119 (2009) [hereinafter Spencer, Habit(us)]. 
ever, the recent New York lawsuit_Jones $v$. Schneiderman ${ }^{3}$ - brought by members of the MMA community alleging a violation of their First Amendment rights, and naming the Attorney General of New York State as the defendant, provides an opening for a theory-based discussion of MMA. This paper's focus will be on the MMA community, utilizing a theoretical framework provided by Boaventura de Sousa Santos' notion of subaltern cosmopolitanism, ${ }^{4}$ and Brian Tamanaha's classification of community/cultural normative system that, ${ }^{5}$ here, forms part of legal pluralism in the social arena within a state. ${ }^{6}$ The discussion will then turn to the strategies for social inclusion and increased legitimacy employed by the MMA community through public interest litigation versus lobbying efforts. Finally, this paper will suggest that success through public interest litigation must not be solely assessed at face value. Instead, public interest litigation facilitates a non-hegemonic use of hegemonic legal tools and structure that a subaltern community/cultural normative system may appropriate in order to represent its interests, its internal rules and norms, and the narratives of its members in a language of the dominant legal frameworkthat of constitutionality and First Amendment rights. I then propose that this dialogue operates as popular constitutionalism where a social movement, through popular resistance and engagement in a dialogue with the judiciary, may instigate a shift in constitutional interpretation and meaning. ${ }^{7}$

\section{But First, What Is MMA?}

Historically, MMA began as a pitting of different forms of martial arts against each other in order to determine the dominant form. MMA has now morphed into a widely televised hybrid style of fighting that occurs in a caged octagon between fighters who deploy the most effective fighting techniques from a range of martial arts against each other. These hybrid forms of fighting can include aspects of shoot wrestling, boxing, judo, taekwondo, Brazilian jiu-jitsu, kickboxing, and

3. Jones v. Schneiderman, 888 F. Supp. 2d 421 (S.D.N.Y 2012) [hereinafter Jones v. Schneiderman].

4. Boaventura de Sousa Santos, Toward a New Legal Common Sense, 458-74 (2nd ed. 2002).

5. Brian Z. Tamanaha, Understanding Legal Pluralism: Past to Present, Local to Global, 30 Sydney L. Rev. 375, 399 (2008).

6. Santos, supra note 4 at 95.

7. Mark Tushnet, Popular Constitutionalism as Political Law, 81 Chi.-Kent L. Rev. 991 (2006); Vanessa MacDonnell, Internet Surveillance and Popular Constitutionalism in Surveillance, Counter-Terrorism and Comparative Constitutionalism 313 (George Williams et al., eds. 2014). 
so forth. The way in which techniques are combined, balanced, and deployed comprises a style that is unique to each fighter as they hone their combat skills or seek victory in the octagon. ${ }^{8}$

\section{Theoretical Framework}

\section{A. MMA as Community/Cultural Normative System}

Within Brian Tamanaha's framework for legal pluralism, he distills six systems of normative ordering that can exist within a social arena. ${ }^{9}$ Of these six, the community created by involvement in MMA-as illustrated by the passage at the outset of this paper-constitutes a community/cultural normative system. ${ }^{10}$ As we will see, MMA community members have shared understandings and commonalities in the structure of their everyday lives, their identities, and their choice of cultural and leisure practices. Added to these internal structuring norms, behaviour, and values that define membership, the community adheres to a set of Uniform Rules that structure the practice of MMA. ${ }^{11}$

In addition to those involved in the practice of MMA, non-fighting community members involved in the MMA community/cultural normative system find their place on the periphery of the practice, including fans, promoters, trainers, etc.

\section{B. Subaltern Cosmopolitanism/Cosmopolitan Legality}

Contact zones, according to Boaventura de Sousa Santos, are "social fields in which different normative life worlds meet and clash."12 They are zones in which "rival normative ideas, knowledges, power forms, symbolic universes and agencies meet in unequal conditions and resist, reject, assimilate, imitate, and subvert each other, giving rise to hybrid legal and political constellations in which the inequality of exchanges are traceable." 13 The legal pluralism that arises within

8. See also Nancy Cheever, The Uses and Gratifications of Viewing Mixed Martial Arts. 4:1 Journal of Sports Media 25 (2009) (a study indicating that this is one of the primary draws of MMA to its viewership base).

9. Tamanaha, supra note 5 at 396-97. Tamanaha uses the term "social arena" as "an empty framing device that can be defined in any way, according to any criteria, that a particular researcher desires. An entire nation can constitute a social arena, as can a local community, or a transnational network of business people" (id. at fn 79). For the purposes of this paper, I will define the social arena in question as that of the State.

10. Id. at 399.

11. Mixed Martial Arts Unified Rules of Conduct, N.J. Admin. Code §13:46-24A (2002) [hereinafter Unified Rules].

12. Santos, supra note 4 at 472.

13. Id. 
these contact zones leads to a cosmopolitan legal struggle that seeks what Santos refers to as "an equality of differences." 14

For the MMA community/cultural normative system, a state's regulatory framework within which MMA events must occur represents a contact zone where complex interactions arise within any given state. ${ }^{15}$ The struggle arises between the internal MMA norms, values, and rules and the formal legal framework established by the dominant group. Facing continued exclusion from the dominant legal framework in certain jurisdictions such as New York State, the MMA community is subaltern in its quest for the legitimacy and recognition of its internal norms, values, and rules. ${ }^{16}$ Santos identifies four types of sociability that arise within contact zones. In the context of the MMA community that seeks legitimacy and incorporation into the dominant legal framework, the type of "contact zone sociability" is that of "conviviality," where the goal is "equal exchanges and shared authority." 17

In terms of legal strategies (or cosmopolitan legality), in order for law to be emancipatory, Santos distills eight conditions or presuppositions of subaltern cosmopolitan legality. ${ }^{18}$ Near the top of his list Santos identifies a condition that corresponds with the MMA community's use of public interest litigation in order to enter into a dialogue with the dominant legal framework. Santos describes this condition as a "non-hegemonic use of hegemonic tools . . premised upon the possibility of integrating them in a broader political mobilizations." 19 Public interest litigation permits the MMA community to formulate their internal norms, values, and rules in the language of the dominant legal order-specifically, constitutionalism and First Amendment rights - in order to communicate in a common language with the aim of achieving an equal exchange with the dominant legal framework. ${ }^{20}$

The MMA community's use of public interest litigation is also only a portion of their broader political mobilization through ongoing lob-

14. Id. at 473 .

15. See also Simon Gardiner et al., Sports Law $76-77$ (4th ed. 2012). See Santos, supra note 4 at 95 for discussion of internal legal pluralism.

16. Santos, supra note 4 at 473 . For a discussion of social exclusion as a product of unequal power relations and exchanges, see id at 459. See also Jordan T. Smith, Fighting for Regulation: Mixed Martial Arts Legislation in the United States, 58:2 Drake L. Rev. 617, 622-24 (2010) (where most sports seek to avoid regulation, MMA seeks to be regulated).

17. Santos, supra note 4 at $473-74$.

18. $I d$. at $466-67$.

19. Id. at 467.

20. Where social exclusion is the product of unequal exchanges, the commonality of language provided by the formal legal dialogue of constitutionality will at least temporarily form the base of equal exchanges. See id. at 459 . For a discussion of language, see id. at $108 \mathrm{ff}$. 
\begin{tabular}{lllll}
\hline |jciprod01 $\backslash$ productn $\backslash \mathrm{D} \backslash \mathrm{DPS} \backslash 11-1 \backslash \mathrm{DPS} 104 . t x t$ & unknown & Seq: 5 & 7-MAY-15 & $10: 39$ \\
\hline
\end{tabular}

bying efforts and grassroots awareness-raising campaigns. ${ }^{21}$ This speaks to Santos' emphasis on the importance of the politicization of struggles before they are legalized. ${ }^{22}$ It will become apparent that the MMA community accomplishes this by using public interest litigation as a last-resort strategy within their arsenal, of which lobbying efforts are the focus. ${ }^{23}$

It is helpful at this point to clarify what I refer to in this context as "public interest litigation".

\section{Public Interest Litigation}

As Scott Cummings and Deborah Rhode note, the precise definition of "public interest litigation" is highly contested.24 The same is true of determining whether or not there is a particular criteria for a case to be considered "in the public's interest." 25 Ultimately, there is no "right" answer since the nature of litigation related to public law issues and social justice broadly represents the interests of society and the different composite groups within a social arena.

\section{i) What Can Public Interest Litigation Bring to a Community/ Cultural Normative System?}

"[L]itigation is a political tool that, when used strategically, can stimulate meaningful change and complement other political efforts." 26 Here, the importance of litigation is in its calculated use in combination with other strategies, ${ }^{27}$ which corresponds to Santos' view of non-hegemonic uses of hegemonic tools within broader political mobilization. ${ }^{28}$ Often in public interest litigation, political transformation is sought rather than a conventional legal victory. ${ }^{29}$ Litigation facilitates a dialogue between the cultural/community normative sys-

21. Daniel Berger, Constitutional Combat: Is Fighting a Form of Free Speech? The Ultimate Fighting Championship and its Struggle Against the State of New York Over the Message of Mixed-parts, 20 Jeffrey S. Moorad Sports Law J. 381, 399 (2013); Layth H. Gafoor et al., Fighting for Certainty: The Legality of Mixed Martial in Canada, Just (June 2013), http://www.justmag.ca/ June2013/feaFightingCertainty_June2013.html; Thomas Hauser, The Boxing Scene 156 (2009). See also Smith, supra note 16 at 624.

22. Santos, supra note 4 at 467.

23. Berger, supra note 21 at 382 , fn. 5 .

24. Scott L. Cummings \& Deborah L. Rhode, Public Interest Litigation: Insights from Theory and Practice, 36:4 Fordham Urb. L.J. 603, 605-606 (2009).

25. Id. See also Ann Southwood, Conservative Lawyers and the Contest Over the Meaning of Public Interest Law, 52 UCLA L. Rev. 1223 (2005).

26. Cummings \& Rhode, supra note 24 at 609.

27. $I d$. at 611 .

28. Santos, supra note 4 at 467.

29. Cummings \& Rhode, supra note 24 at $609,611-12$. 
tems and the dominant legal structures embodied in formal (hegemonic) court proceedings. This dialogue not only serves an awarenessraising function with the aim of provoking a paradigm shift within the dominant social and legal order, ${ }^{30}$ but it also fosters community-building within subaltern cosmopolitan groups seeking to use litigation to advance their causes. "[W]hether litigation 'works' or not must be judged in relation to available alternatives." 31 The potential for litigation to lead to social change in a particular situation requires an examination of the context within which it occurs - the political, economic, cultural, organizational, and institutional milieu. ${ }^{32}$ In the context of MMA, the New York State Senate has passed a bill that would legalize MMA in New York in each of the last several years; however the bill has been repeatedly blocked from reaching the floor of the State Assembly. ${ }^{33}$ This has led to an environment in which litigation is one of the only remaining alternative. ${ }^{34}$

\section{ii) The Evolving Nature of Public Interest Litigation}

While MMA may appear to be an unconventional application of public interest litigation and argumentation regarding unconstitutionality, it is also important to keep in mind that public interest litigation has evolved over the years to address causes of a greater ideological bend-including interests chiefly related to commerce. ${ }^{35}$ As noted by Laura Beth Nielsen and Catherine Albiston, public interest law is no longer confined to its traditional realms of the economically and socially disadvantaged or subaltern. ${ }^{36}$ It has instead expanded to address both liberal and conservative interests, the interests of the middle class, as well as the socially and economically powerful and dominant portions of society. ${ }^{37}$

30. Id. at 610 .

31. $I d$. at 609 .

32. $I d$.

33. See e.g. Franklin McNeil, MMA Bill Passes in NY Committee, ESPN NEw York (Feb. 28, 2013), http://espn.go.com/new-york/story/_/id/9000470/bill-legalize-mma-new-york-passes-statesenate-committee-cultural-affairs-tourism-parks-recreation; Alan Snel, UFC Officials Again Try to Make Their Case in New York State, Las Vegas Review-Journal (Feb. 25, 2014), http:// www.reviewjournal.com/business/ufc-officials-again-try-make-their-case-new-york-state. See also Matthew Dondiego, MMA Supporters Begin 2014 Push to Legalize Sport: Fighters Come to Albany to Discuss Benefits of the Sport, The Legislative Gazette (Feb. 3, 2014), http://www .legislativegazette.com/Articles-Top-Stories-c-2014-02-03-86631.113122-MMA-supporters-begin2014-push-to-legalize-sport.html .

34. Berger, supra note 21 at 382 , fn. 5 .

35. See e.g. Laura Beth Nielsen \& Catherine R. Albiston, The Organization of Public Interest Practice: 1975-2004, 84 N.C. L. Rev. 1591, 1598 (2006).

36. Id. at 1620 .

37. Id. 
Regardless of whether or not this development is viewed favourably, studying new forms of public interest litigation ensures a broader and more contemporary understanding of the field of public interest lawyering and avoids marginalizing particular portions of the practice. ${ }^{38}$ The reality, as stated by Nielsen and Albiston, is that "[p]rivate power has realized that it too can lay claim to the mantle of 'public interest'.."39

Nonetheless, while the driving actors behind MMA lobbying and public interest may have commercial interests in achieving greater legitimacy and a sanctioned presence within the dominant legal order, their work is also driven by a concern for the advancement of the sport of MMA as well as the safety and well-being of MMA participants. ${ }^{40}$ This is a tangible example of the comingling interests of both public and private realms, and the application of subalternity to both.

\section{iii) Narratives as Effective Evidence for Public Interest Litigation}

The method of illustrating the importance of MMA as a sport, cultural, or leisure activity-or, in this case, the impact of the New York ban of live professional MMA - is quantified and qualified via the narratives of the members of the MMA community/cultural normative system. The plaintiffs seek to demonstrate the role of MMA in their lives. In other words, their narratives—or, the stories they tellshow the way in which each of them individually experience and understand the law banning live professional MMA events and how this law, or ban, impacts their lives. ${ }^{41}$

The narratives of these "ordinary" people allows for a case study in legal consciousness. ${ }^{42}$ Studying the strategies these plaintiffs deploy in

\footnotetext{
38. Id. at 1598 .

39. Id. at 1620-21.

40. Smith, supra note 16 at 624. See also Tom Wright's (UFC Director of Operations in Canada) statement regarding the recent legalization of MMA in Canada: "The work that we've done in Ottawa has been for the sport of MMA, not just UFC. "People say it's self-serving. Sure it is. But when we got the changes in Ontario, the first year, we held two events and I think there were 20 other events across the province that wouldn't have happened if it wasn't for the work for that sport that we championed" (Dave Meltzer, Major Day for MMA Legislation as Bills Pass in Canada and Connecticut, MMA Fighting (June 5, 2013), http://www.mmafighting.com/ 2013/6/5/4400386/major-day-for-mma-legislation-as-bills-pass-in-canada-and-connecticut.)

41. This is also an example of what Ewick \& Silbey would term "law in society" as opposed to "law and society": Patrick Ewick \& Susan S. Silbey, The Common Place of Law: Stories from Everyday Life (1998). See also Sally Engle Merry, Legal Pluralism and Legal Culture: Mapping the Terrain in Legal Pluralism and Development: Scholars and Practitioners in Dialogue 66 (Brian Z. Tamanaha et al., eds. 2012) [hereinafter Merry, Legal Pluralism].

42. Ewick \& Silbey, supra note 41 at 35; Laura Beth Nielsen, Situating Legal Consciousness: Experiences and Attitudes of Ordinary Citizens about Law and Street Harassment, 34 Law \& Soc'y Rev. 1055, 1058-59 (2000).
} 
order to engage, avoid, or resist the law, enables an understanding of how "ordinary" people understand, experience, and construct legality. ${ }^{43}$

Patrick Ewick and Susan Silbey's study of how ordinary Americans recount their experiences of the problems they face in their lives discloses a finite set of categories into which their narratives can be placed. ${ }^{44}$ These categories reveal three distinct schemas of how individuals define their relationships to law, how they view themselves in the world, and how they participate in the construction of legality. ${ }^{45}$ Ewick and Silbey suggest that these three narratives, or forms of legal consciousness, will demonstrate their experience of the law as: (1) before the law, where law is separate and discontinuous from everyday life and is a "formally ordered, rational, and hierarchical system of known rules and procedures" that is fixed, objective, and impartial; ${ }^{46}$ (2) with the law, where law is to be engaged with, is interlaced with everyday life, and is a game that may be played strategically for particular gains ${ }^{47}$ with lawyers as highly skilled experts in the game, ${ }^{48}$ and where there is an effective and powerful benefit to collective/team action; 49 or (3) against the law, where law is to be passionately resisted or fleetingly avoided and where respite must be sought from its power in order to maintain a sense of dignity. ${ }^{50}$

\section{iv) Public Interest Litigation as Narrative}

I argue that in addition to the narratives of individuals, and of the plaintiffs in Jones $v$. Schneiderman, public interest litigation itself may be viewed as a narrative. In viewing public interest litigation through the lens of a narrative or form of legal consciousness, it is then possible to see a reason for its strategic use. When deployed specifically by the plaintiffs in Jones $v$. Schneiderman-or, generally, by a social movement-litigation demonstrates the second category identified above by Ewick and Silbey. In this context, the litigants are acting out their relationship with the law, where law is a game that may be played strategically, with the help of lawyers as the skilled experts in the game and with the power derived from collective action, in order to access a particular outcome or to foster its flexibility in responding to

\footnotetext{
43. Ewick \& Silbey, supra note 41 at 35, 45; Nielsen, supra note 42 at 1058-59.

44. Ewick \& Silbey, supra note 41 at 47. See also Merry, Legal Pluralism, supra note 41 at 71.

45. Ewick \& Silbey, supra note 41 at $45-47$.

46. Id. at 47.

47. Id. at 48 .

48. Id. at $152-56$.

49. Id. at $156-58$.

50. Id. at 48-49.
} 
a desired paradigm shift. It demonstrates why litigation, even if only arguably effective, is nonetheless sought by social movements as a tool for negotiating with dominant legal or cultural frameworks.

\section{Popular Constitutionalism and Public Interest Litigation}

The theory of popular constitutionalism is helpful in measuring the success of public interest litigation. The central tenant of this theory, of which there are various iterations, is that popular opinion should be reflected in constitutional meaning and interpretation. ${ }^{51}$ This is accomplished through judicial observation of social movements and subaltern interests. ${ }^{52}$ Considered in this manner, the success of public interest litigation is not in the legal win or loss but rather success is achieved through the dialogue fostered by the community/cultural normative system with the presiding judge.

Before further filtering MMA and the case study of Jones $v$. Schneiderman through the above theoretical framework, it will be helpful to gain an understanding of the history of MMA, and the current state of its legality in Canada and the United States-specifically within the state of New York.

\section{The History of MMA}

MMA is one of the fastest growing sports in America. ${ }^{53}$ It outsells boxing in pay-per-view buys and is even used in military training by the United States. ${ }^{54}$ Its roots can be traced back through history to circa 648 B.C. and its Olympic ancestor: the ancient sport of Pankration, a combination of Hellenic boxing and wrestling. In Pankration, only eye-gouging and biting were prohibited and matches usually progressed until the opponents were on the ground utilizing a variety of techniques in order to eventually attain victory through either the surrender, unconsciousness, or death of one of the opponents. ${ }^{55}$

51. See e.g. MacDonnell, supra note 7; Tushnet, supra note 7; BARRy Friedman, The WiLL of the People: How Public Opinion Has Influenced the Supreme Court and Shaped the Meaning of the Constitution (2009) [hereinafter Friedman, Will]; Barry Friedman, $M e$ diated Popular Constitutionalism, 101 Mich. L. Rev. 2596 (2003).

52. Tushnet, supra note 7 at 998-99.

53. Miles Adam Park, In the Octagon: Mixed Martial Arts Comes to Life in 3 American History Through American Sports: From Colonial Lacrosse to Extreme Sports 295 (Danielle S. Coombs \& Bob Batchelor, eds. 2013)

54. Smith, supra note 16 at 618; Park, supra note 53 at 308.

55. Michael Kim, Mixed Martial Arts: The Evolution of a Sport and its Laws and Regulations, 17 Sports Law. J. 49, 50-51 (2010); Smith, supra note 16 at 620; Jones v. Schneiderman, supra note 3 at 5 . 
As was mentioned above, the origins of MMA as we know it can be summarized as an interest in determining the comparative dominance of different fighting techniques and styles. ${ }^{56}$ While early events were structured as a fighting contest between fighters who aligned themselves with a particular martial arts style,57 eventually the different forms of combat sports were mixed together and evolved into a hybrid form of mixed disciplines combining elements of floor and standing grappling with striking combat.

In the lead-up to the increasingly widespread popularity of MMA, American audiences, in particular, demonstrated an interest in the pitting of different styles against each other in order find the superior form. ${ }^{58}$ Many of these early fights were advertised as "no-holdsbarred" where rules, or the lack thereof, were characterized by an "anything goes" mentality, save for the prohibition against weapons. ${ }^{59}$

The popularity of these early MMA events was magnified by the technology permitting their wide dissemination and availability, in addition to being immortalized in the late 1980s and early 1990s in films such as Street Fighter and Mortal Kombat, based on the wildly successful video games of the same name. ${ }^{60}$

Parallel to the MMA format gaining popularity in the United States, events designed to find the dominant fighting style occurring in Brazil benefitted from the same technology enabling their widespread exposure to a broad audience. ${ }^{61}$ However, a focus on maintaining a realistic element to the fight and the fighting techniques employed, which favoured an "anything goes" approach, constituted a noticeable difference in the Brazilian permutation of MMA. ${ }^{62}$ In Brazil, the vale tudo form, characterized by this "anything goes" mentality and a carnivalesque atmosphere, became extremely popular. ${ }^{63}$ Within vale tudo fighting challenges, the Gracie Family pioneered a unique genre of fighting that would become known popularly as Brazilian jui-jitsu.

56. Raul Sanchez Garcia \& Dominic Malcolm, Decivilizing, Civilizing or Informalizing? The International Development of Mixed Martial Arts, 45:1 Int'l Rev. Soc. of Sport 39, 43 (2010). For a detailed discussion of the development of MMA as well as resources for a greater understanding of the nuances of the sport, see: Clyde Gentry, No Holds Barred Fighting and the Martial Arts Revolution (2004); Jonathan Snowden, Total MMA: Inside Ultimate Fighting (2008); Jonathan Snowden \& Kendall Shields, The MMA Encyclopedia (2010); Park, supra note 53.

57. Spencer, Habit(us), supra note 2 at 121.

58. Park, supra note 53 at 297.

59. See e.g. id. at 296.

60. Id. at 298-99.

61. Id. at 299.

62. Id. at 299.

63. Smith, supra note 16 at 620. 
The Gracie Family based their style of fighting on Japanese jui-jitsu and dominated the vale tudo. ${ }^{64}$

Even in the United States, jiu-jitsu rose above the fray as the most effective fighting technique. Jui-jitsu held the attention of American audiences, as it could allow comparably smaller fighters to triumph over much larger opponents. ${ }^{65}$ This created an element of accessibility and inclusivity that other forms of combat did not provide to the ordinary viewer or fan. This aspect of "accessibility" remains a hallmark of MMA and its promotion. Taking former UFC welterweight champion George St. Pierre as an example, there are tangible elements throughout his semi-autobiographical work, GSP: The Way of the Fight, which allow the "ordinary" person to see themselves becoming a champion fighter. ${ }^{66}$ The idea is instilled within the reader that maybe if one were to put in the work and follow the routine, tips, and advice provided, then maybe-just maybe-it would be possible to become a champion. This element is also evidenced in the narratives deployed by the fighters in communicating with the public and the press-the stories they tell of their lives and specifically their growth and experiences as MMA fighters often include tales of past hardships.

The combination of the Brazilian and American desire to distill the most effective fighting technique, with the added dimension of the realistic use of the most effective technique, led to MMA as we know it today. ${ }^{67}$ The final step in this development occurred in the late 1990s when attention shifted from the dominant fighting technique or martial art and instead focused on the individual fighter and each fighter's unique strategic combination of different techniques to secure a victory. 68

\section{A. Enter the Ultimate Fighting Championship}

The Ultimate Fighting Championship ("UFC") is an important element in the development of MMA as well as its growing popularity.

64. Id. For an explanation of how they developed their form of Brazilian jui-jitsu, see Greg Downey, Producing Pain: Techniques and Technologies in No-Holds-Barred Fighting, 37:2 Soc. Studies of Sci. 201, 204-205 (2007) [hereinafter Downey, Producing]; Berger, supra note 21 at 388-390.

65. Park, supra note 53 at 297.

66. Georges St. Pierre \& Justin Kingsley, GSP: The Way of the Fight (2013). See also Dale C. Spencer, Ultimate Fighting and Embodiment: Violence, Gender, and Mixed Martial Arts (2012) [hereinafter Spencer, Ultimate Fighting]; Green, supra note 1. Boxing has also been viewed in the same manner. For a well-known ethnographical and sociological study of a "regular" person transforming themselves into a boxer, see: LoÏc WACQuANT, Body \& Soul: Notebooks of AN Apprentice Boxer (2004).

67. Park, supra note 53 at 299.

68. Spencer, Habit(us), supra note 2 at 121. 
Considering the parallel American and Brazilian interest in distilling the most effective fighting technique, it is fitting that the genesis of WOW Productions - which would eventually become the UFC-came about in 1992 through the partnership between an American businessman and the entrepreneur, Brazilian jiu-jitsu expert, and head of the Gracie Family, Rorion Gracie. ${ }^{69}$ The objective of the first event, an eight man "no-holds-barred" style elimination tournament called The Ultimate Fighting Championship, was to find the best fighter through pitting different forms of martial arts against each other in a realistic setting with a lack of weight categories and time limits, victory only achieved through knockout, submission, or referee stoppage/abandonment, and with the only rules being the prohibition of strikes to the groin, eye-gouging, or biting. ${ }^{70}$ It was at this point that the emblematic chain-link octagon became the chosen setting for MMA fights. ${ }^{71} \mathrm{Be}-$ yond the attendees at the first event, which took place on November 12, 1993 at the McNichols Sports Arena in Denver, Colorado, the payper-view availability of the live professional event led to the immediate success of the enterprise ${ }^{72}$ and remains an element of the UFC's popularity and the continued proliferation of MMA. These first UFC events focused on spectacle over sport and often had relatively brutal outcomes due to the lack of rules. ${ }^{73}$

Certainly the UFC was not the only organization promoting and organizing live professional MMA events; there were many others that played a role in the increasing popularity of the burgeoning sport. ${ }^{74}$ However, the new owners of UFC (Zuffa LLC) bought out and continue to buy out the other MMA organizations, in addition to finding alternate ways to dominate the sport. The very name, UFC, has now become synonymous with MMA. ${ }^{75}$

\section{B. Finding Acceptance as a Sport}

Securing an audience base does not necessarily secure acceptance as a sport. The initial success and popularity of MMA and the UFC eventually ran into resistance in the form of public and political criti-

69. Park, supra note 53 at 299-300.

70. Id. at 300; Spencer, Habit(us), supra note 53 at 121; Garcia \& Malcolm, supra note 56 at 45; Peter Hess, The Development of Mixed Martial Arts: From Fighting Spectacles to State-Sanctioned Sporting Events 4:1 Willamette Sports L.J. 1 (2007).

71. Park, supra note 53 at 300.

72. Id.

73. Smith, supra note 16 at $621-22$.

74. For a discussion of other organizations, see e.g. Park, supra note 53 at 306.

75. As Park accurately states, "In more ways than one, the history of mixed martial arts is the history of the Ultimate Fighting Championship." (Id. at 307). 
cism of the legality and morality of the sport-largely due the common and serious injuries that resulted from the lack of rules that characterized the matches. ${ }^{76} \mathrm{~A}$ moral campaign against live professional MMA events as well as their television presence put the early90s success of the UFC into a dark era during the late-90s. ${ }^{77}$ A number of states within the United States went so far as to enact bans against MMA events.

In discussing the history of MMA and the initial ban against it in thirty-six states including New York, it would be remiss not to mention United States Senator from Arizona John McCain's infamous definition of MMA as "human cockfighting" and the 1996-97 crusade he led against the sanctioning of MMA in the United States. ${ }^{78}$ When he publicly retracted this statement ten years later, ${ }^{79}$ it was largely due to the rise of stricter MMA rules as well as a conscious movement away from sensationalizing promotional techniques such as shock advertising. ${ }^{80}$

MMA's re-emergence began in 2001 as the UFC was welcomed by Las Vegas promoters and bought by Zuffa LLC. The new co-owners Lorenzo and Frank Fertitta, and new UFC president Dana White, rebranded the company and focussed on anti-barbaric presentation as well as the implementation of more developed rules and safety precautions. These efforts were intended to (and successfully managed to) ease public criticism, and this led to increased marketability. ${ }^{81}$ With the eventual intent in mind to increase the legitimacy and public credibility of MMA as a sport, the UFC developed a policy where UFC events would not be held in states without a state athletic commission that oversaw and regulated MMA. ${ }^{82}$ They also sought uni-

76. Smith, supra note 16 at 622.

77. Park, supra note 53 at 301-302; 308; Smith, supra note 16 at 622.

78. Others vocally against the sanctioning of MMA included New York State Senator Roy Goodman, as well as Mayor Rudy Giuliani, and New York State Assemblyman Bob Reilly. Miles Park, supra note 53 at 301. Kim, supra note 55 at 52; Ladan Shelechi, Say Uncle: New York's Chokehold Over Live Performance of Mixed Martial Arts: Whether Combat Sports are Protectable Speech and How Much Regulation is Appropriate for Inherently Dangerous Sports,33 Loy. L.A. Ent. L. Rev. 205, 213-14 (2013), Berger, supra note 21 at 381, 405; Garcia \& Malcolm, supra note 56 at 52. President of the American Medical Association also took up this argument by publicly stating that "far from being legitimate sports events, ultimate fighting contests are little more than human cockfights where human gladiators battle bare-knuckled until one gives up, passes out or the carnage is stopped by a doctor or referee. The rules are designed to increase the danger to the fighters and to promote injury rather than prevent it" (Garcia \& Malcolm, supra note 56 at 51-52).

79. Berger, supra note 21 at 405.

80. See e.g. Garcia \& Malcolm, supra note 56 at 52-54; Berger, supra note 21 at 404.

81. Park, supra note 53 at 302-303; Smith, supra note 16 at 622.

82. Id. at 623; Park, supra note 53 at 300. 
formity in the rules and safety procedures of all UFC events, regardless of where events were held. ${ }^{83}$ Uniformity was necessary for the safety of fighters so that all parties were aware of and competing under the same rules. ${ }^{84}$

\section{UFC and the Public/Private Interest}

It is in relation to UFC's insistence on proper regulation that private interests intersect with that of the public. The UFC's investment in educating legislators and lobbyists is not solely for commercial business interests, but also in the public interest wherein lies a concern for the safety of fans and competitors and the well-being and growth of the sport of MMA. These concerns have situated the UFC as the main force behind legislative efforts towards the proper regulation of MMA in all states and provinces. ${ }^{85}$

\section{The Unified Rules of Mixed Martial Arts (Unified Rules)}

Probably the most significant response to the MMA community's desire for greater legitimacy and public acceptance, was the progress made towards promoting the legality of MMA through the codification of the Unified Rules of Mixed Martial Arts by the New Jersey State Athletic Control Board in 2000 and their subsequent adoption in April of 2001. ${ }^{86}$ The Nevada State Athletic Commission and the California State Athletic Commission soon followed New Jersey's lead, as did numerous other sporting regulatory bodies and athletic commissions. ${ }^{87}$

New Jersey's decision to proceed in this manner overcame its initial reluctance to sanction MMA events due to health and safety concerns originating from the dearth of formal rules. The tides turned in favour of the UFC and MMA when the New Jersey Athletics Control Board noted the voluntary efforts by MMA event promoters, such as the UFC, to develop and implement internal sets of rules intended to work towards becoming state sanctioned. ${ }^{88}$

The rules themselves grew out of the numerous different sets of rules and regulations in use at the time by various states and MMA organizations. A three-hour meeting organized by the New Jersey State Athletic Control Board Commissioner on April 3, 2001, resulted

83. Smith, supra note 16 at 623 .

84. Hess, supra note 70 at 15.

85. See supra note 40 and accompanying text.

86. Unified Rules, supra note 11.

87. Smith, supra note 16 at 627.

88. Id. at 626. 
\begin{tabular}{lllll}
\hline |jciprod01 $\backslash$ productn $\backslash \mathrm{D} \backslash \mathrm{DPS} \backslash 11-1 \backslash \mathrm{DPS} 104 . t x t$ & unknown & Seq: 15 & 7-MAY-15 & 10:39 \\
\hline
\end{tabular}

in a consensus as to a set of rules. ${ }^{89}$ Commonly known simply as the "Unified Rules", 90 these rules have become standard for MMA events and are adopted widely in the regulatory frameworks that oversee MMA. ${ }^{91}$

\section{MMA REgulation AND Legality}

The standard approach within the US and Canada is for the state or province to delegate the regulation of MMA to a body or agency that specializes in overseeing athletics-related policy and regulatory manners-often athletic commissions. ${ }^{92}$ These sanctioning bodies will then develop rules and regulations that address MMA in a comprehensive manner. Matters covered include the manner in which the matches will be conducted - the judging of matches, for example - and deal in large part with concerns linked to the safety of the fighters, such as weight classes, medical and safety requirements and precautions. ${ }^{93}$ Other requirements addressed include licensing, registration, taxes, and fees. ${ }^{94}$ Another approach to regulation may see the state or province statutorily adopt the relevant rules and regulations and then direct that, by law, the regulatory body or athletic commission implement the Unified Rules. ${ }^{95}$

Whichever mechanism is used to regulate MMA, the resulting rules, regulations, or statutes, are generally similar to the regulations in place in Nevada. The UFC is vocally partial to the Nevada regulations since the many events held in Nevada have facilitated an ironing out of the kinks in order to create what are viewed as the most practical, complete, and efficient set of regulations available. ${ }^{96}$ As noted previously, in addition to dealing with licensing, registration, fees, and taxes, the Nevada regulations implement the Unified Rules.

89. Id. at 627 .

90. For a current and accessible version of the Unified Rules, see the UFC's iteration: Unified Rules and other MMA Regulations, Discover UFC, http://www.ufc.com/discover/sport/rulesand-regulations (last visited Feb. 6, 2015). But see also Unified Rules, supra note 11.

91. See e.g. Smith, supra note 16 at 627-28 for the American context. In Canada, an example of the implementation of the Unified Rules is Ontario's Athletics Control Act, R.R.O. 1990, Reg. 52 (Can.). However one notable exception to the widespread use of the Unified Rules is the Province of Quebec's Regulation Respecting Combat Sport, C.Q.L.R., c. S-3.1, O.C. 686-98, s.1 (Can.): Quebec legalizes MMA under "mixed boxing" and does not approve MMA under the Unified Rules.

92. See e.g. Smith, supra note 16 at 625 .

93. Id. at 634-37.

94. Id. at 626. For an in-depth discussion of the mechanics of regulating MMA through delegation as well as other options, see id at 628-30.

95. Id. at 629-30.

96. $I d$. at 631 . 
The Unified Rules themselves are considered to be the most important component of a state or province's regulations as it is through these rules that MMA has been able to address concerns regarding the safety of fighters as well as set itself apart from its prior, more brutal forms of the sport, such as the aforementioned Pankration, vale tudo, and earlier American MMA-style fights from the early 1990s. ${ }^{97}$

The Unified Rules prohibit thirty-one fouls and other acts and specify the different ways in which a fight can end: submission, technical knockout, knockout, and decision. ${ }^{98}$ In terms of a decision, the Unified Rules lay out the criteria for how judges are to arrive at their decision-thus providing uniformity and (arguably) transparency in the adjudication of the fight. The Unified Rules also identify medical precautions and testing that must be adhered to and create allowances for the referee to stop a fight when it is perceived that the safety of one of the competitors is at risk. ${ }^{99}$

\section{A. The Canadian Context}

In Canada, MMA events were officially decriminalized in June 2013 with the passing of Bill S-209. ${ }^{100}$ However, MMA events may nonetheless only be held if they meet the new stipulations under section 83(2) of the Canadian Criminal Code requiring that events adhere to provincial or municipal regulations. ${ }^{101}$ As with the majority of bodies that now regulate MMA events at provincial, municipal, or state levels, the Uniform Rules are incorporated into the regulatory framework. ${ }^{102}$

\section{B. The New York Context}

With the continuing wave of legalization and sanctioning of MMA events, New York stands out as one of the last bastions to be conquered by the burgeoning sport. New York is the only remaining major state that deems live professional MMA events illegal—and this is

97. Id. at 634 .

98. See Uniform Rules, supra note 11. The clear delineation that a fight can end in manners other than rendering one of the competitors unconscious or seriously injured is important in order to counteract public misconceptions. See Smith, supra note 16 at 636.

99. For example, the referee is permitted to end the a fight if the referee determines that a competitor has a sustained an injury, if a competitor is at risk of injury due to the one-sided nature of a fight, or if one of the competitors is thought to be competing dishonestly: Id.

100. An Act to Amend the Criminal Code (prize fights), S. 209, 1st Sess. 41st Parl. (2013) (assented to June 19, 2013) (Can.).

101. Canada Criminal Code, R.S.C. 1985, c. C-46 s. 83.

102. See e.g. Athletics Control Act, R.R.O. 1990, Reg. 52 (Can.). 
not for a lack of extensive lobbying efforts and money that the UFC has poured into having the Ban on MMA removed. ${ }^{103}$

As discussed above, the MMA Ban in New York did not always exist. Rather, it was one of the products of the 1996-97 campaign led by John McCain against the sanctioning of MMA events. Prior to the Ban, the New York State Athletic Commission ("NYSAC") had no jurisdiction over MMA; it only had regulatory control over boxing, sparring, and wrestling. All of this changed when "combative sports" were essentially legalized by the passing of Senate Bill 7780 in October 1996 and placed within the jurisdiction of the NYSAC. ${ }^{104}$ MMA events then required a license from NYSAC in order to be held. This initially posed no problem and a license was acquired for an upcoming event. However, a week prior to the next scheduled UFC eventNYSAC introduced a set of temporary rules governing MMA events that directly contravened those implemented by the UFC in past events. ${ }^{105}$ NYSAC's rules would have significantly altered the format of MMA events within the state and changed many of MMA's key elements. The new temporary rules were also contrary to the UFC's recent transition towards greater uniformity and standardization of the internal rules of the sport. ${ }^{106}$ The UFC decided to protest, turning to the courts to file a preliminary injunction in order to keep NYSAC from enforcing its new rules and instead accept the UFC's rule book. ${ }^{107}$ Ultimately this proved unsuccessful and soon after, on 25 February 1997, a new statute was signed into law that disallowed "combat sports" unless they were regulated through the NYSAC, or one of the exempt organizations such as the World Karate Association. This ban disallowing professional MMA within New York State remains effective today as New York's Unconsolidated Law section 8905-a. ${ }^{108}$

MMA falls under the Ban's definition of "combat sports": "A 'combative sport' shall mean any professional match or exhibition other than boxing, sparring, wrestling or martial arts wherein the contestants deliver, or are not forbidden by the applicable rules thereof from delivering kicks, punches or blows of any kind to the body of an opponent or opponents." 109 The Ban creates criminal and civil penalties for

\footnotetext{
103. Hauser, supra note 21 at 156; Berger, supra note 21 at 382.

104. Id. at 402 .

105. $I d$. at $402-403$.

106. Park, supra note 53 at 623.

107. Berger, supra note 21 at 403.

108. N.Y. UnCON. LAws $§ 8905$-a (Combative Sports) [hereinafter Ban].

109. "Martial arts", on the other hand, are defined to include "any professional match or exhibition sanctioned by any of the following organizations: US Judo Association, US Judo, Inc,
} 
"knowingly advanc[ing] or profit[ing] from a combative sport activity." 110

As the defendants in Jones $v$. Schneiderman have revealed, the initial motivating objectives behind the 1997 legislation that set the Ban in place, can be summarized as the following: (1) the risk of injury faced by the participants, (2) the potential effect on youth, and (3) a concern with the "civilization" or "disgust" factor, and perception that MMA events are "barbaric" or "savage". ${ }^{111}$ The defendant maintains that "there remains intact some if not all of the rational bases that were behind the law when passed."112

The stubborn maintenance of this ban allows for the practical demonstration of a community/cultural normative system that is led to consider all of the available tools in their arsenal when faced with a situation where lobbying does not yield results. 2013 marks the sixth straight year of lobbying to have the New York Ban removed. In what has become the usual chain of events, each year the State Senate passes the MMA bill that would remove the Ban against live professional MMA events in New York, but the Speaker subsequently blocks it from reaching the Assembly floor. ${ }^{113}$

\section{The Grassroots Movement}

A grassroots movement has developed in relation to the sport of MMA and is especially prominent in struggles to have the sport recog-

US Judo Federation, US Tae Kwon Do Union, North American Sport Karate Association, USA, Karate Foundation, US Karate, Inc., World Karate Association, Professional Karate Association, Karate International, International Kenpo Association, or World Wide Kenpo Association" (id).

110. The Ban clarifies that one knowingly advances the combative sports when

"acting other than a spectator, he or she engages in conduct which materially aids any combative sport. Such conduct includes but is not limited to conduct directed toward the creation, establishment or performance of a combative sport, toward the acquisition or maintenance of premises, paraphernalia, equipment or apparatus therefor, toward the solicitation or inducement of person to attend or participate therein, toward the actual conduct of the performance thereof, toward the arrangement of any of its financial or promotional phases, or toward any other phase of combative sport" (id.).

The Ban also clarifies that "[a] person profits from a combative sport activity when he or she accepts or receives money or other property with intent to participate in the proceeds of a combative sport activity, or pursuant to an agreement or understanding with any person whereby he or she participates or is to participate in the proceeds of a combative sport activity." (Id.)

111. Jones v. Schneiderman, Defendant's Reply to Complaint, supra note 3 at 7-8. See also, Berger, supra note 21 at 404-405.

112. Jones v. Schneiderman, Defendant's Reply to Complaint, supra note 3 at 8.

113. See supra note 33 and accompanying text. 
nized and sanctioned in particular jurisdictions. ${ }^{114}$ As opposed to the traditional desire of most sports organizations to avoid increased government regulation and oversight, the MMA community seeks regulation and oversight in the ongoing pursuit of greater legitimacy and acceptance. ${ }^{115}$

\section{A. Grassroots in New York - Lobbying and Litigation}

In New York, the grassroots popularity of the MMA community is prolific and works for the removal of New York's ban against live professional MMA events through both lobbying efforts and supplemented by public interest litigation. ${ }^{116}$ These two approaches are used in a complimentary manner. The plaintiffs in Jones $v$. Schneiderman have sought to galvanize the members of the grassroots movement largely through the hiring of Global Strategy Events by Zuffa LLC, the backbone behind the lawsuit. ${ }^{117}$ The objectives are to raise fan awareness of MMA and the fact that it remains unsanctioned in New York, to foster support within the community for the efforts towards sanctioning live professional MMA events, and to build a positive public opinion about legalizing the sport in New York. ${ }^{118}$ To that end, Zuffa LLC has also hired the Albany-based lobbying firm Brown, McMahon \& Weinraub to push for the development of MMA legislation. ${ }^{119}$

\section{B. Grassroots in Canada - Lobbying and Litigation}

Though an in-depth analysis of Canada's reasons for legalizing MMA via the recent passage of Bill S-209120 (and the prior sanctioning of professional MMA events, such as in Ontario) is beyond the scope of this paper; however, significant grassroots and awarenessraising efforts contributed to the eventual paradigm shift and modernizing of Canada's Criminal Code. ${ }^{121}$ As stated in commentary leading

114. See also Green's study into the community developed through the practice of MMA: supra note 1. See also, generally: Spencer, Ultimate Fighting, supra note 66 and Spencer, Habit(us), supra note 2. For application in the boxing context, see Wacquant, supra note 66.

115. See also Smith, supra note 16.

116. See e.g. the Coalition to Legalize Mixed Martial Arts in New York, http://nymma now.blogspot.com (last visited Feb. 6, 2015).

117. See United Fighting Championship, Global Strategy Group, http://globalstrategy group.com/case-studies/ultimate-fighting-championship/ (last visited Feb. 6, 2015).

118. Berger, supra note 21 at 406.

119. $I d$.

120. An Act to Amend the Criminal Code (prize fights), S. 209, 1st Sess. 41st Parl. (2013) (assented June 19, 2013) (Can.).

121. But see Layth H. Gafoor et al., Fighting for Certainty: The Legality of Mixed Martial in Canada, Just (June 2013), http://www.justmag.ca/June2013/feaFightingCertainty_June2013.html. 
up to the passing of the bill: "MMA has established its seat at the main table of major sports in North America. It is an example of how a new and emerging sport, through its grass root popularity, can influence policy making and legislation." 122 As opposed to the situation in New York, the grassroots movement in Ontario found success in changing the regulatory framework purely through lobbying efforts. ${ }^{123}$

There are limited examples of litigation in Canada regarding sanctioning of combat sports, the most relevant of which is $R v$. Chang. ${ }^{124}$ In this case, Mr. Chang promoted an event called the "Extreme Fighting Championship". This 2002 event, held in Saint John, New Brunswick, involved the use of a variety of combat techniques. At the time, section 83(2) of the Canadian Criminal Code allowed boxing matches as long as they were sanctioned by an athletic board or commission appointed by the province. Since New Brunswick had no appointed board or commission, Mr. Chang's event violated section 83(2). During the proceedings, the presiding judge had to determine whether the event fell under section 83's exemption for boxing contests or if it constituted a "prize-fight". In referring to the Ontario case $R$. $v$. M.A.F.A., ${ }^{125}$ the judge determined that Mr. Chang's event constituted a "prize-fight". However, in the judge's concluding remarks, he suggested that if these types of combat sports were becoming publicly acceptable due to their increased popularity, then regulations would be required for the safety of the contestants. The judge was careful to note that such a change would be the purview of legislators rather than the courts. He suggested that lobbying could lead to change and that the court should only intervene if there is an infringement of Charter rights. ${ }^{126}$

122. Id.

123. A plethora of news sources discuss the push towards having Ontario sanction professional MMA events. While events had been held previously, they were unregulated. As this source describes, and consistent with their past behaviour, the UFC avoids holding events in jurisdictions where MMA is not regulated (Elaine Wiltshire, Ontario legalizes mixed martial arts, 30:22 Lawyer's Weekly 14 (Oct. 2010). See also Jeff Gray, 'Rising Star' Wins Legal Bout for Mixed Martial Arts, The Globe And Mail (Dec. 21, 2010) http://www.theglobeandmail.com/ report-on-business/industry-news/the-law-page/rising-star-wins-legal-bout-for-mixed-martialarts/article1213759.

124. R. v. Chang, 2003 NBPC 11 [hereinafter Chang].

125. Here, the accused was found guilty of organizing a "prize-fight" under $\S 83$ for organizing a kickboxing competition. The event had not been sanctioned by Ontario's Athletics Commission, so it was not regulated by Boxing Ontario, and thus contravened $\S 83$ of the Criminal Code (R. v. M.A.F.A. Inc., [2000] O.J. No 899 (Ct. J.) (Can. Ont.)).

126. Chang, supra note 121. 
\begin{tabular}{lllll}
\hline |jciprod01 $\backslash$ productn $\backslash \mathrm{D} \backslash \mathrm{DPS} \backslash 11-1 \backslash \mathrm{DPS} 104 . t x t$ & unknown & Seq: 21 & 7-MAY-15 & $10: 39$ \\
\hline
\end{tabular}

\section{MMA Community Membership}

\section{A. Importance of the Professional MMA Event}

One of the interesting peculiarities of the Ban on live professional MMA events in New York is that amateur events are generally permitted-the vagueness and inconsistent allowance of which is noted by Judge Wood in Jones $v$. Schneiderman. ${ }^{127}$ While the allowance of amateur events is seemingly at odds with the reason for the Ban in the first place (the risk of participant injury, the dangerous and wrong message delivered to "our youth" and the "effect upon youth", as well as the "civilization" or "disgust" factor), ${ }^{128}$ permitting them has limited significance within the MMA community since it is the professional event in particular that serves an important purpose to the community. As Dale Spencer notes, in a thorough ethnography based on his participation in MMA, all participants in his study agreed that participating in at least one professional MMA event constitutes "a widely recognized rite of passage" that is essential to truly "becoming" a MMA fighter. ${ }^{129}$ Participants in Spencer's study agree that the legitimization spoken of is acquired through a shared community knowledge and understanding that the significance of participating in the professional MMA event can only be understood by those who have entered the octagon. ${ }^{130}$

Spencer also notes the difficulty faced by Ontario MMA fighters before the Ontario Athletic Commission sanctioned professional MMA events (due to their illegal status under section 83 of the Canadian Criminal Code)-fighters would have to leave the province of Ontario in order to take part in these MMA events that are central to the practice of MMA and around which identity in the community is structured. ${ }^{131}$

In addition to the link between participating in a professional event and "becoming" a MMA fighter, Spencer describes the role that learning particular fighting techniques also plays in developing an identity as a MMA fighter. ${ }^{132}$ Spencer distinguishes between the techniques developed by MMA athletes and other sports by noting the

127. Jones v. Schneiderman, supra note 3 at 47-50.

128. Id. (Defendant's Reply Memorandum of Law in Support of Initial Limited Motion to Dismiss the Fourth and Fifth Causes of Action in the Complaint at 7-8 [hereinafter Defendant's Reply to Complaint]); Berger, supra note 21 at 404.

129. Spencer, Ultimate Fighting, supra note 66; Spencer, Habit(us), supra note 2 at 135-36.

130. Spencer, Ultimate Fighting, supra note 66 at 73-74; at 144.

131. Id. at 154 .

132. Id. at 126 . 
\begin{tabular}{lllll}
\hline |jciprod01 $\backslash$ productn $\backslash \mathrm{D} \backslash \mathrm{DPS} \backslash 11-1 \backslash \mathrm{DPS} 104 . t x t$ & unknown & Seq: 22 & 7-MAY-15 & $10: 39$ \\
\hline
\end{tabular}

112 DEPAUL J. SPORTS L. \& CONTEMP. PROBS. [Vol. 11:91

higher level of pain that MMA fighters must endure in the process of developing their technique-what he terms "body callusing"-in order to harden their bodies and turn them into a weapon that they will then deploy in the octagon. ${ }^{133}$ The importance of the particular techniques developed and then deployed by the MMA fighter in the ring can thus be seen as an integral part of their identity. ${ }^{134}$ "[T] $[\mathrm{T}$ he mixing of styles and the ?ghter's bodily predisposition to ?nd particular body techniques more useful than others, makes every fighter an original articulation, in varying degrees different than other fighters." 135

\section{JONES V. SCHNEIDERMAN}

\section{A. Overview}

Turning to the case study at issue, the case of Jones $v$. Schneiderman continues to progress through the court system. The latest action in the lawsuit initiated against New York State-filed specifically against the New York State Attorney General-was the Defendant's Motion to Dismiss based on Federal Rules of Civil Procedure 12(b)(6). ${ }^{136}$

In their first cause of action, the plaintiffs assert that MMA's expressive conduct as live entertainment is suppressed by the New York State's Combative Sports Ban ("the Ban") and is thus unconstitutional and in violation of the fighters' First Amendment rights to free speech and expressive conduct. Ultimately the balance of the claim boils down to whether or not mixed martial artists actually transmit a message to crowds who pay to watch them perform during live professional MMA events, and whether or not fans understand the intended message.

Specifically, the plaintiffs argue that the Ban is invalid because the law: "(1) violates Plaintiffs' First Amendment rights of expression; (2) is overbroad on its face, in violation of the First Amendment; (3) is unconstitutionally vague, in violation of the Due Process Clause; (4) violates the Equal Protection Clause; (5) lacks a rational basis, in violation of the Due Process Clause; and (6) violates the Commerce Clause." 137

133. Id. at 127,133 .

134. Id. at 135 .

135. Id. at 137. See also Cheever, supra note 8: this is one of the elements that attracts MMA fans.

136. Jones v. Schneiderman, supra note 3 at 17; FED. R. Civ. P. 28.

137. Jones $v$. Schneiderman, supra note 3 at 2-3. In relation to the ban, the plaintiffs are also argue that First Amendment rights of expression are violated by a separate 2001 liquor law (id. at 3 ). 
\begin{tabular}{lllll}
\hline |jciprod01 $\backslash$ productn $\backslash \mathrm{D} \backslash \mathrm{DPS} \backslash 11-1 \backslash \mathrm{DPS} 104 . t x t$ & unknown & Seq: 23 & 7-MAY-15 & $10: 39$ \\
\hline
\end{tabular}

At the time of this writing, of these six claims, only the unconstitutional vagueness (as-applied) has not been dismissed. While this is a small victory, it remains that the First Amendment right of expression constituted an important portion of the plaintiffs' case and that the dismissal of the four other claims results in a significant reduction in the substance of their case. Moving forward, depositions were scheduled for March 2014 according to the "Scheduling Order" submitted to the court. Commentators surmise that New York will attempt to submit a motion for summary judgment to dismiss the as-applied unconstitutional vagueness claim and that, if the plaintiffs' are able to avoid another motion to dismiss, then a trial is likely to occur in 2014. ${ }^{138}$

Due to the limited scope of this paper, I will focus primarily on the arguments advanced regarding the plaintiffs' First Amendment right of expression as well as their arguments regarding the unconstitutional vagueness of the Ban.

\section{B. First Amendment Rights}

The Plaintiffs' First Amendment arguments take two directions. The first is that the Ban is a content-based restriction on their free speech and expressive conduct, and the second is that the Ban is overbroad. While the court ultimately rejects the plaintiffs' First Amendment arguments, it is not the final formal legal result that carries value for the present examination. Instead, as noted previously, it is the process and dialogue created that is valuable.

\section{i) Narratives As Evidence}

In order to establish that MMA constitutes expressive conduct, the plaintiffs must first demonstrate an intent to convey a particularized message. In order to accomplish this the plaintiffs utilize their narratives, stories they can recount from their lives, as well as those of MMA community members. Their narratives can be classified into three different particularized messages: artistic, technical, and personal.

In responding to the plaintiffs' use of their narratives, at the outset of the its decision, the court identifies the plaintiffs by listing their name, their ring name, and their particular connection to the MMA community. This sets the stage for the dialogue between the parties and the court regarding MMA's alleged message. The plaintiffs are

138. Jason Cruz, 13 for 13: No. 8 Zuffa Still Shut Out in New York, MMAPAyout.com (Dec. 24, 2013), http://mmapayout.com/2013/12/13-for-13-no-8-zuffa-still-shut-out-in-new-york/. 
\begin{tabular}{lllll}
\hline |jciprod01 $\backslash$ productn $\backslash \mathrm{D} \backslash \mathrm{DPS} \backslash 11-1 \backslash \mathrm{DPS} 104 . t x t$ & unknown & Seq: 24 & 7-MAY-15 & $10: 39$ \\
\hline
\end{tabular}

114 DEPAUL J. SPORTS L. \& CONTEMP. PROBS. [Vol. 11:91

given a face and an identity that is maintained in the text of the decision. Some examples of the stories of MMA community members are included below.

\section{a) Artistic Message Conveyed}

At the time of the proceedings, Jon "Bones" Jones was the UFC Light Heavyweight Champion and the youngest to hold a title in the history of the UFC. ${ }^{139}$ Jones speaks to the pre-fight performance, notably during the entrance into the arena (the "walkout") and the message conveyed through a fighter's choice of entrance music (their "theme" music), the battle clothing that is carefully picked out and worn during the walkout, and the fighter's conduct while in the octagon. ${ }^{140}$ In the text of the decision, Judge Wood recognizes Jones's narrative and the particular personas constructed by the fighters and backstories they establish, which are not only on display during the walkout as well as the fight itself, but are also the focus of much of the pre-fight advertising and promotional material. ${ }^{141}$

In describing the live professional MMA event as a performance, the plaintiffs liken it to other art forms that must be attended by an audience in a "live" context in order to truly be appreciated and experienced, such as a dance show, a concert, or theater. For example, Frankie "The Answer" Edgar, a former UFC Lightweight champion, describes his dream to perform in Madison Square Garden-much as an actor might dream of performing on Broadway. Edgar asserts that that his performance cannot be wholly appreciated unless it is experienced live. ${ }^{142}$

Brian Stann is a UFC fighter and military veteran who received the Silver Star medal and is the president of a non-profit organization called Hire Heroes USA, which supports military veterans seeking employment and reintegration into everyday civilian life. ${ }^{143}$ In addition to the personal message that Stann seeks to convey to his fans, he also finds that performing live enables him to truly communicate his message to the fans-notably to fellow military veterans. ${ }^{144}$

139. Id. at 3.

140. Shelechi, supra note 78 at 214-15; Jones v. Schneiderman, supra note 3 at 13-14.

141. Id. at $13-14$.

142. Id. at 3; Shelechi, supra note 78 at 214-15.

143. Jones $v$. Schneiderman, supra note 3 at 4.

144. Shelechi, supra note 78 at 215. 


\section{b) Technical Message Conveyed}

Judge Wood acknowledges the narratives of MMA fans by noting the argument that fans "learn, understand, and respond to the technical aspect of MMA. They understand that the strikes, holds, and moves are carefully planned and executed" and are drawn to MMA by the "athleticism, skill, and display of contrasting styles of fighting." 145

Joseph Lozito is also listed as a plaintiff. His story is not only relevant because he is a fan who lives in New York and would like to attend live professional MMA events, but Lozito reveals that he once subdued a murderer carrying a knife on the subway by using techniques he had observed by viewing UFC pay-per-views of MMA. ${ }^{146}$

\section{c) Personal Message Conveyed}

Jon "Bones" Jones is again referenced by Judge Woods to recognize the argument that in "the way [Jones] performs in fights and carries himself generally, Jones strives to send the messages of faith, self-confidence, and self-esteem to his fans. . . He fights to convey to his fans that their dreams can come true if they work hard and do their best." 147

Gina "Conviction" Carano also appears in the text of the judge's opinion. Carano is seen by many as one of the most influential female MMA fighters. ${ }^{148}$ Judge Wood references the plaintiffs' arguments: "Carano performs MMA live because it allows her to connect with other fight[er]s, as well as with outsiders, and send a message about the strength and determination of women to succeed."149

Matt "The Hammer" Hamill recently retired from UFC fighting and is congenitally deaf. Judge Wood recognizes the argument that by performing, Hamill hopes to send the message to deaf athletes that they should not to let a disability turn them away from following their dreams. ${ }^{150}$

Judge Wood also cites the plaintiffs' arguments noting that certain fans "identify with the personal stories of particular professional

145. Jones v. Schneiderman, supra note 3 at 14.

146. Jones v. Schneiderman, supra note 3 at 4; Jim Genia, Deconstrucing Zuffa's Lawsuit Against New York, MMA Convert (Nov. 15, 2011), http://www.mmaconvert.com/2011/11/15/ deconstructing-zuffa $\%$ E2\% $80 \% 99$ s-lawsuit-against-new-york/.

147. Jones v. Schneiderman, supra note 3 at 14.

148. Id. at 3.

149. Id. at 14 .

150. Id.; Shelechi, supra note 78 at 215. 
MMA fighters" and find the experienced to be magnified upon attending a live MMA event. ${ }^{151}$

\section{ii) Judge Wood's Decision}

Referring to Zalewska v. County of Sullivan, Judge Wood states that the conduct of an individual will not necessarily be viewed as speech simply because the individual intends to express an idea. ${ }^{152}$ Not only must there be an intent to convey a "particularized message", there must also be a "great likelihood that the message will be understood by those viewing it." 153 As a result, in addition to the individual fighter's subjective intent, there is a crucial objective component that must be considered to assess whether the conduct in question will be understood by its recipient to convey a particular message. ${ }^{154}$ The burden is on the party arguing for First Amendment protection to establish beyond a merely "plausible contention" that their conduct is expressive. ${ }^{155}$

Bearing this in mind, Judge Wood finds that while the plaintiffs have subjectively demonstrated intent to communicate a particularized artistic, technical, or personal message, ${ }^{156}$ they have not successfully established that objectively there is a "great likelihood" that the viewership will understand their particular message. ${ }^{157}$ The ultimate result is that the plaintiffs do not effectively demonstrate that MMA is "sufficiently imbued with the elements of communication" to qualify for First Amendment protection. ${ }^{158}$

Judge Wood carefully notes that this decision is free of aesthetic or moral judgment of MMA, ${ }^{159}$ and then addresses the allegedly artistic component of the message conveyed by MMA. Judge Wood emphasizes the competitive conduct component of MMA, as a sport, which is defined by a winner and a loser. ${ }^{160}$ Where the courts have predominantly refused to accord First Amendment protection to sports, Judge Wood contrasts the competitive conduct that characterizes sports to

151. Jones $v$. Schneiderman, supra note 3.

152. Id. at 19, citing Zalewska v. Cnty. of Sullivan, 316 F.3d 314, 319 (2d Cir. 2003) [hereinafter Zalewska].

153. Id. at 19, citing Zalewska, supra note 149 at 319.

154. Jones v. Schneiderman, supra note 3 at 20. 2004).

155. Id., citing Church of Am. Knights of the Ku Klux Klan v. Kerik, 356 F.3d 197, 205 (2d Cir.

156. Jones v. Schneiderman, supra note 3 at 21-22.

157. Id. at 20-23.

158. Id. at 20, citing Texas v. Johnson, 491 U.S. 397, 403, 109 S. Ct. 2533, 105 L. Ed. 2d 342

(1989). See also Jones v. Schneiderman, supra note 3 at 29

159. Id. at 22 .

160. Id. at 23 . 
public performances-for which the courts have established do communicate an expressive message. ${ }^{161}$

Judge Wood highlights that not all "live entertainment" necessarily qualifies for First Amendment protection and draws out the nuances of particular Olympic sports, such as figure skating, that are "on the periphery of protected speech."162 But even considering the potential of the minimal degree of protection, Judge Wood does not find peripheral protection applicable in this case. ${ }^{163}$

Turning to the alleged technical message conveyed and the plaintiffs' argument: that there is an element of speech in how fighters construct and contrast their performances in terms of the style of martial arts used, strategies deployed, and technique exhibited, Judge Wood finds that this is typical of organized competition in showing the superiority of the technique of one side over the other. ${ }^{164}$ She writes that "[i]f such a 'message' were sufficient to trigger constitutional protection, the line between conduct and speech would be meaningless." 165 Judge Wood goes on to explain that the impressiveness of a particular skill does not necessarily qualify the related conduct for First Amendment protection. She ultimately concludes that "[m]usic, dance, and theatrical performance are protected because, whether amateur or professional, slap-stick or high-society, such activities are primarily intended to express a message to the viewer. Live professional MMA, by contrast, lacks such essential communicative elements," regardless of "[t]he fighters' pre-fight and post-fight antics" as this constitutes the "surrounding fanfare" rather than the conduct itself that is supposed to "convey the particularized message that the audience is likely to receive." 166

Turning next to the plaintiffs" argument that "professional MMA matches and exhibitions inherently qualify for First Amendment protection because the conduct entertains a live audience," 167 Judge Wood finds that, if this were the case, it "would subsume nearly every intentional act done in the presence of another person."168 Judge Wood explains that public occurrence of conduct does not necessarily render unprotected conduct protected. She refers to the US Supreme Court's finding that while nude dancing might fall within the periphery of First

\footnotetext{
161. Id. at 23-24.

162. Id. at $24,26-27$.

163. Id. at 27.

164. Id. at $27-28$.

165. Id. at 28 .

166. Id. at 29-30.

167. Id. at 30 [emphasis in original].

168. Id. at 31 .
} 
Amendment protection, engaging in sexual conduct in public does not render it protected, nor does the act itself constitute protected expression. ${ }^{169}$

\section{C. $\quad$ Void for Vagueness}

While the plaintiffs were unsuccessful forwarding their interests framed in the language of First Amendment rights, they succeeded in having the judge refuse to dismiss their void for vagueness claim. Their victory on this count is less related to the use of narratives and the human component of MMA community membership, and is instead primarily the result of inconsistency, contradictions, and backpeddling on the part of the defendants. However, narratives are still deployed as evidence.

\section{i) Narratives as Evidence}

The account of Shannon Miller illustrates the vagueness claim advanced by the plaintiffs regarding the erratic application of the Ban. Miller is a producer of MMA events and "[i]n 2009, Miller had planned to hold an amateur Muay Thai and kickboxing event at the State University of Albany. A UFC fighter was scheduled to appear at the event, but not to compete. The New York State Athletic Commission however, citing the "professional" appearance of the posters used to promote the event, shut down the event." 170 This occurred even though amateur events, as will be explained below, were not (and are not) banned.

Don Lilly is a MMA promoter who manages both amateur and professional MMA fighters as well as owning a MMA gym in New York. ${ }^{171}$ Again in support of the plaintiffs' vagueness argument, Lilly recounts his story of an amateur event he held in North Tonawanda, New York with over 1000 attendees. ${ }^{172}$ This is used in argumentation to show that the NYSAC allowed amateur events even though it, at times, stated that, to the contrary, amateur events were also illegal. ${ }^{173}$ Lilly's experience also reveals that NYSAC instructed Lilly that MMA events were only legal if they occurred on Indian reservations, whereas the Attorney General at other times stated the Ban remained

169. Id. at 31-32, citing City of Erie v. Pap's AM, 529 U.S. 277, 289, 120 S. Ct. 1382 (2000); Connection Distrib. Co. v. Reno, 154 F.3d 281, 289 n.8 (6th Cir. 1998); Paris Adult Theatre I v. Slaton, 413 U.S. 49, 67, 93 S. Ct. 2628 (1973); O'Connor v. City \& Cnty. of Denver, 894 F.2d 1210, 1218 (10th Cir. 1990).

170. Id. at 5 .

171. Id. at 5 .

172. $I d$.

173. Id. at 17,48 . 
enforceable regardless of whether or not professional live events occurred on reservation lands. ${ }^{174}$

\section{ii) Judge Wood's Decision}

In advancing their vagueness claim, the plaintiffs highlight the erratic history of the Ban's enforcement. The defendants contest that this is irrelevant, however Judge Wood disagrees. ${ }^{175}$ Instead, Judge Wood considers the evidence the plaintiffs provide in support of this claim. The plaintiffs allege that only UFC-sponsored events were prohibited between when the Ban came into force in 1997 and until 2002, and that not only were both amateur and professional non-UFC-sponsored events common, but that NYSAC members even attended these events. ${ }^{176}$ The plaintiffs go on to explain that after 2002, both amateur and professional combative sport events were shut down, and that it was made known that any amateur MMA events remaining in New York State would be shut down by staff and members of NYSAC. ${ }^{177}$ Judge Wood finds that, where the Ban does not provide a definition of either "professional" or "amateur", the plaintiffs sufficiently allege that the NYSAC has not applied a consistent interpretation of the two words. ${ }^{178}$ The judge also notes the defendants mostly ignore their erratic application of the two terms in enforcing the ban. ${ }^{179}$

In addition, according to the plaintiffs, while MMA events were strictly monitored, other combative sporting events such as kickboxing, began to be held with NYSAC's approval. This was due to the Ban's exception that martial arts could still occur in New York as long as they were sanctioned by specifically enumerated exempt organizations, such as the World Karate Association. ${ }^{180}$ However, the plaintiffs allege that the World Karate Association is the only enumerated organization that has been allowed to promote combative sporting events. ${ }^{181}$ The plaintiffs also point out that the NYSAC now argues that amateur MMA events are not banned. ${ }^{182}$ Judge Wood also considers the defendant's change in position regarding whether or not a professional MMA event would be allowed if sanctioned by one of the

174. Id. at 53 .

175. Id. at 42-43.

176. Id. at 15 .

177. Id.

178. Id. at 47-51.

179. Id. at 48 .

180. Id. at 16 .

181. $I d$.

182. $I d$. 
enumerated exempt organizations. ${ }^{183}$ While the defendants at first clearly agreed that an exempt organization could sanction a combative sport that would otherwise be banned, Judge Wood notes that the defendants then reversed their opinion only weeks later to assert that a professional combative sport event would nonetheless still be banned even if sanctioned by an exempt organization. ${ }^{184}$ As a result the court finds in favour of the plaintiffs agreeing that the law is unconstitutionally vague concerning the sanctioning of professional MMA events by exempt organizations. ${ }^{185}$

The plaintiffs also assert that the Ban is unconstitutionally vague regarding professional MMA events held on Indian reservations in New York State and that contradictory statements have been issued by the Attorney General. Judge Woods does not dismiss this particular as-applied challenge since the defendants do not address the matter of Ban enforceability and jurisdiction on sovereign Indian reservations. ${ }^{186}$

Ultimately, Judge Wood finds that the plaintiffs have sufficiently formulated an as-applied vagueness challenge regarding the defendant's inconsistent treatment among "professional MMA sanctioned by exempt organizations, amateur MMA, and professional MMA events on Indian reservations." 187 Accordingly, Judge Wood turns to the plaintiffs' facial vagueness challenge, but determines that the plaintiffs do not successfully meet the heavier burden required to establish this claim. ${ }^{188}$

\section{Lobbying Versus Public Interest Litigation}

A critique of the use of litigation instead of political strategiessuch as organizing and social activism - is that political strategies tend to result in long-term change as well as carrying an air of greater legitimacy while simultaneously accessing the community building and engagement that occurs when utilizing litigation as a tool towards social change. ${ }^{189}$ However, this is not necessarily true and legislative successes may face subversion to the same extent as successes gained via the litigation route, especially where a subaltern community/cultural normative systems are involved. ${ }^{190}$

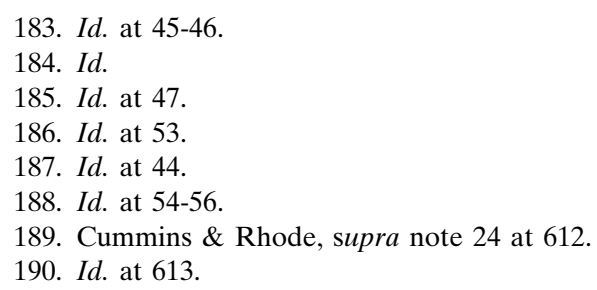


In addition, Sandra Fredman observes that where the legislature may be dominated by interest group bargaining, public interest litigation can permit the legal and judicial forum to serve as a place for a democratic conversation between all interested parties on equal terms. ${ }^{191}$ This speaks to the link, noted previously, that Santos makes between social exclusion and unequal exchanges-and a potential manner of recalibrating the relationship in order to establish an equality of differences between subaltern groups and the dominant order. ${ }^{192}$ Public interest litigation allows ordinary people to nonhegemonically seize hegemonic tools in order to oblige government accountability and justification in the court's forum for government actions or inactions. 193 As Judge Wood states, the defendant (the "government") does not adequately provide this justification or explanation on account of the as-applied vagueness complaint forwarded by the plaintiffs. ${ }^{194}$

\section{A. Public Interest Litigation as the Last Recourse}

The UFC first approached the New York ban through lobbying-as has traditionally been their approach in other states as well as in Canada. ${ }^{195}$ However, as described by the plaintiff's lawyer, Barry Friedman, after over five years of lobbying and suspended hope in the continued efforts to pass a bill in the State Senate that would overturn the Ban, the MMA community turned to the courts, and public interest litigation, as the last remaining option. ${ }^{196}$

Litigation provides a venue to advance norms and values that remain unrecognized in the dominant legal framework by facilitating an audience with the judicial branch of government and opens a forum for dialogue between this potentially mitigating force and the opposing party (attorney general or administrative agencies) which is connected to the legislative branch of government. This audience as well as the awareness raised as a result of forcing this dialogue is invaluable in pushing forward subaltern interests and values. As such, public

191. Sandra Fredman, Human Rights Transformed: Positive Rights and Positive Duties 149 (2008); see also Gauri, Varun, Public Interest Litigation in India: Overreaching or Underachieving?, THE WORLD BANK (Nov. 2009), http://www-wds.worldbank.org/external/de fault/WDSContentServer/IW3P/IB/2009/11/03/000158349_20091103104346/Rendered/PDF/WPS 5109.pdf at 5; Santos, supra note 4 at 467.

192. Id. at 457.

193. Fredman, supra note 134 at 148.

194. Jones v. Schneiderman, supra note 3 at 45-46.

195. Berger, supra note 21at 399; Gafoor, Waldron \& Ghazi, supra note 21; Hauser, supra note at 156. See also Smith, supra note 16 at 624.

196. Berger, supra note 21 at 382 , fn 5. 
interest litigation is a solid tool. Nonetheless, it is only one of the tools within the larger tool box of strategies-predominantly political-in pursuing public interest causes that ideally lead to a paradigm shift within dominant legal and cultural orders. ${ }^{197}$

\section{B. Is Jones v. Schneiderman Simply Dressing Itself Up as Public Interest Litigation?}

While the concern remains that public interest litigation may now be dominated by lifestyle issues and middle class concerns to the detriment of the economically marginalized and disadvantaged, ${ }^{198}$ Nielsen and Albiston, as cited above, make a solid case for the expansiveness in the interests now addressed by public interest litigation.

While there may be a concern that cases such as Jones $v$. Schneiderman are simply "dressing themselves up" as public interest causes, ${ }^{199}$ perhaps a current reality of the evolving nature of public interest litigation is that it exists to represent subaltern interests and values amidst otherwise equal citizens.

In addition to viewing the plaintiffs in this lawsuit as members of a community/cultural normative system, it is also possible that they constitute what Ferraz refers to as a privileged litigating minority. ${ }^{200} \mathrm{Con}-$ trary to what the name of the case might suggest, in addition to many other plaintiffs representing "all aspects of amateur and professional MMA", the monetary reality necessary in bringing this lawsuit indicates that the majority stakeholders are Zuffa LLC (doing business under UFC) - self-proclaimed as "the leading promoter of live Professional MMA contests and exhibitions throughout the world."201 This, however, does not necessarily change the basic principles behind their claims, nor does it change the value of studying their struggles for professional MMA events to become sanctioned in New York.

\section{Conclusion: Popular Constitutionalism and Success}

In conclusion, when determining the success of public interest litigation in this context, there are two questions to ask: (1) is litigation a successful or effective tool by which to advance causes in the public interest which may be harnessed by social movements in working towards a paradigm shift where their interests gain recognition by the

197. Cummins \& Rhode, supra note 24 at $609-11$.

198. Gauri, supra note 18 at 3.

199. Id. at 2.

200. Octavio Luiz Motta Ferraz, Harming the Poor Through Social Rights Litigation: Lessons from Brazil, 89 Tex. L. Rev. 1643, 1646 (2011).

201. Jones v. Schneiderman, supra note 3 at 3. 


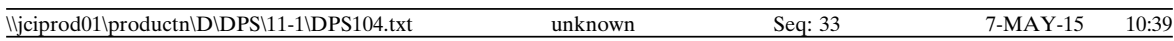

dominant legal and/or social order; and (2) has litigation been a successful mechanism in the ongoing battle towards the sanctioning of live professional MMA events in the State of New York?

In short, as explained throughout this article, the answer to the first question is yes, while the answer to the second question remains to be seen.

As Tamara Kagan suggests, engagement with legal systems leads to a rethinking and potential dismantling of preconceived notions. ${ }^{202} \mathrm{Re}-$ gardless of whether litigation results in a successful claim, it can foster a political dialogue pertaining to the incapacity of the legal system to effectively comprehend and recognize alternate perspectives, frameworks, practices, or value systems. ${ }^{203}$

The identity of the UFC's lawyer in Jones v. Schneiderman, Professor Barry Friedman, provides perhaps the best clue as to the motivation behind the use of public interest litigation and the true success of the endeavour, beyond what may be perceived as a face-value loss on the First Amendment right of expression claim. Professor Barry Friedman is a scholar who works in the area of popular constitutionalism. He explains that it is the dialogue entered into with the courts that is ultimately valuable: "This give-and-take between the courts and the people is of the utmost consequence, for through it the substance of constitutional law itself is forged." 204 As Mark Tushnet, another scholar of popular constitutionalism writes: "Judges observing the social movement and its effects on society change their views about what the Constitution means."205

In this sense, the ultimate victory is in the awareness raised by creating an active expression of popular constitutionalism in order for MMA as a community cultural normative system to non-hegemonically use hegemonic tools in order to formulate its subaltern interests within the framework of the dominant legal order with the aim of shaping the future of constitutional law.

202. Tamara Kagan, Recovering Aboriginal Property at Common Law: A Contextual Approach, 63:1 U.T. Fac. L. Rev. 1, 19 (2005).

203. Id. at 19.

204. Friedman, Will, supra note 51 at 384.

205. Tushnet, supra note 7 at 998-99. 


\section{LEGISLATION}

Mixed Martial Arts Unified Rules of Conduct, N.J. Admin. Code $\S 13: 46-24 \mathrm{~A}$ (2002)

An Act to Amend the Criminal Code (prize fights), S. 209, 1st Sess. 41st Parl. (2013) (assented to June 19, 2013) (Can.)

Athletics Control Act, R.R.O. 1990, Reg. 52 (Can.)

Canada Criminal Code, R.S.C. 1985, c. C-46 s. 83

Fed. R. Civ. P. 28

N.Y. UnCON. Laws §8905-a (Combative Sports)

Province of Quebec's Regulation Respecting Combat Sport, C.Q.L.R., c. S-3.1, O.C. 686-98, s.1 (Can.)

\section{JURISPRUDENCE}

Church of Am. Knights of the Ku Klux Klan v. Kerik, 356 F.3d 197(2d Cir. 2004)

City of Erie v. Pap's AM, 529 U.S. 277, 120 S. Ct. 1382 (2000)

Connection Distrib. Co v. Reno, 154 F.3d 281 (6th Cir. 1998)

Jones v. Schneiderman, 888 F. Supp. 2d 421 (S.D.N.Y 2013)

Jones v. Schneiderman, 888 F. Supp. 2d 421 (S.D.N.Y 2013) (Defendant's Reply Memorandum of Law in Support of Initial Limited Motion to Dismiss the Fourth and Fifth Causes of Action in the Complaint)

O'Connor v. City \& Cnty. of Denver, 894 F.2d 1210(10th Cir. 1990)

Paris Adult Theatre I v. Slaton, 413 U.S. 49, 93 S. Ct. 2628 (1973)

R. v. Chang, 2003 NBPC 11 (Can.)

R. v. M.A.F.A. Inc., [2000] O.J. No 899 (Ct. J.) (Can. Ont.)

Texas v. Johnson, 491 U.S. 397, 109 S. Ct. 2533, 105 L. Ed. 2d 342 (1989)

Zalewska v. Cnty. of Sullivan, 316 F.3d 314 (2d Cir. 2003)

Secondary Material: Monographs

Ewick, Patrick \& Susan S. Silbey, The Common Place of Law: STORIES FROM EVERYDAY LIFE (1998)

Fredman, Sandra, Human Rights Transformed: Positive Rights And Positive Duties (2008)

Friedman, Barry, The Will of the People: How Public Opinion Has Influenced the Supreme Court and Shaped the Meaning of the Constitution (2009)

Gardiner, Simon, et al., Sports Law (4th ed. 2012)

Gentry, Clyde, No Holds Barred Fighting and the Martial Arts Revolution (2004) 
Hauser, Thomas, The Boxing Scene (2009)

MacDonnell, VAnessa, Internet Surveillance and Popular Constitutionalism in Surveillance, Counter-Terrorism And COMparative Constitutionalism 313 (George Williams et al., eds. 2014).

Merry, Sally Engle, Legal Pluralism and Legal Culture: Mapping the Terrain in Legal Pluralism and Development: Scholars and Practitioners in Dialogue 66 (Brian Z. Tamanaha et al., eds. 2012)

Park, Miles Adam, In the Octagon: Mixed Martial Arts Comes to Life in American History Through American Sports: From Colonial Lacrosse to Extreme Sports 295 (Danielle S. Coombs \& Bob Batchelor, eds. 2013)

Santos, Boaventura de Sousa, Toward a New Legal Common SENSE (2nd ed. 2002)

Snowden, Jonathan \& Kendall Shields, The MMA EncyclopeDIA (2010)

Snowden Jonathan, Total MMA: Inside Ultimate Fighting (2008)

Spencer, Dale C., Ultimate Fighting and Embodiment: VioLence, Gender, and Mixed Martial Arts (2012)

St. Pierre, Georges \& Justin Kingsley, GSP: The Way of the Fight (2013)

Wacquant, LoÏc, Body \& Soul: Notebooks of an Apprentice BOXER (2004)

\section{Secondary Materials: Articles}

Berger, Daniel, Constitutional Combat: Is Fighting a Form of Free Speech? The Ultimate Fighting Championship and its Struggle Against the State of New York Over the Message of Mixed Martial Arts, 20 Jeffrey S. Moorad Sports Law J. 381 (2013)

Cheever, Nancy, The Uses and Gratifications of Viewing Mixed Martial Arts, 4:1 J. of Sports Media 25 (2009)

Cruz, Jason, 13 for 13: No 8 Zuffa Still Shut Out in New York, MMPAYOUT.COM (December 24, 2013) http://mmapayout.com/ 2013/12/13-for-13-no-8-zuffa-still-shut-out-in-new-york/

Cummings, Scott L. \& Deborah L. Rhode, Public Interest Litigation: Insights from Theory and Practice, 36:4 Fordham Urb. L.J. 603 (2009)

Dondiego, Matthew, MMA Supporters Begin 2014 Push to Legalize Sport: Fighters Come to Albany to Discuss Benefits of the Sport, The Legislative Gazette (Feb. 3, 2014), http://www.legisla- 
tivegazette.com/Articles-Top-Stories-c-2014-02-03-86631.113122MMA-supporters-begin-2014-push-to-legalize-sport.html

Downey, Greg, Producing Pain: Techniques and Technologies in NoHolds-Barred Fighting, 37:2 Soc. Studies of Sci. 201 (2007)

Ferraz, Octavio Luiz Motta, Harming the Poor Through Social Rights Litigation: Lessons from Brazil, 89 Tex. L. Rev. 1643, 1646 (2011)

Friedman, Barry, Mediated Popular Constitutionalism, 101 Mich. L. Rev. 2596 (2003).

Gafoor, Layth H., Paul Waldron \& Hashim Ghazi, Fighting for Certainty: The Legality of Mixed Martial in Canada, Just (June 2013), http://www.justmag.ca/June2013/feaFightingCertainty_ June2013.html

Garcia, Raul Sanchez \& Dominic Malcolm, Decivilizing, Civilizing or Informalizing? The International Development of Mixed Martial Arts, 45:1 Int'l Rev. Soc. of Sport 39 (2010)

Gauri, Varun, Public Interest Litigation in India: Overreaching or Underachieving?, The World BANK Research Working PAPER 5109 (Nov. 2009), http://www-wds.worldbank.org/external/de fault/WDSContentServer/IW3P/IB/2009/11/03/000158349_200911 03104346/Rendered/PDF/WPS5109.pdf

Genia, Jim, Deconstrucing Zuffa's Lawsuit Against New York, MMA Convert (Nov. 15, 2011), http://www.mmaconvert.com/2011/11/ 15/deconstructing-zuffa \% E2\%80\%99s-lawsuit-against-new-york/

Gray, Jeff, 'Rising Star' Wins Legal Bout for Mixed Martial Arts, THE Globe And MaIL (Dec. 21, 2010), http://www.theglobeandmail .com/report-on-business/industry-news/the-law-page/rising-starwins-legal-bout-for-mixed-martial-arts/article1213759/

Green, Kyle, It Hurts So Real: Sensing the Seduction of Mixed Martial Arts, 12:4 Soc. \& Cultural Geography 377 (2011)

Hess, Peter, The Development of Mixed Martial Arts: From Fighting Spectacles to State-Sanctioned Sporting Events, 4:1 Willamette Sports L.J. 1 (2001)

Kagan, Tamara, Recovering Aboriginal Property at Common Law: A Contextual Approach, 63:1 U.T. Fac. L. Rev. 1 (2005)

Kim, Michael, Mixed Martial Arts: The Evolution of a Sport and its Laws and Regulations, 17 Sports Law J. 49 (2010)

McNeil, Franklin, MMA Bill Passes in NY Committee, ESPN New York (Feb. 28, 2013), http://espn.go.com/new-york/story/_id/ 9000470/bill-legalize-mma-new-york-passes-state-senate-commit tee-cultural-affairs-tourism-parks-recreation

Meltzer, Dave, Major Day for MMA Legislation as Bills Pass in Canada and Connecticut, MMA Fighting (June 5, 2013), http:// 
www.mmafighting.com/2013/6/5/4400386/major-day-for-mma-leg islation-as-bills-pass-in-canada-and-connecticut

Nielsen, Laura Beth, Situating Legal Consciousness: Experiences and Attitudes of Ordinary Citizens about Law and Street Harassment, 34 Law \& Soc'y Rev. 1055 (2000)

Nielsen, Laura Beth \& Catherine R. Albiston, The Organization of Public Interest Practice: 1975-2004, 84 N.C.L. Rev. 1591 (2006)

Shelechi, Ladan, Say Uncle: New York's Chokehold Over Live Performance of Mixed Martial Arts: Whether Combat Sports are Protectable Speech and How Much Regulation is Appropriate for Inherently Dangerous Sports, 33 Loy. L.A. Ent. L. Rev. 205 (2013)

Smith, Jordan T., Fighting for Regulation: Mixed Martial Arts Legislation in the United States, 58:2 Drake L. Rev. 617 (2010)

Snel, Alan, UFC Officials Again Try to Make Their Case in New York State, Las Vegas Review-Journal (Feb. 25, 2014), http://www .reviewjournal.com/business/ufc-officials-again-try-make-theircase-new-york-state

Southworth, Ann, Conservative Lawyers and the Contest Over the Meaning of Public Interest Law, 52 UCLA L. Rev. 1223 (2005)

Spencer, Dale C, Habit(us), Body Techniques and Body Callusing: An Ethnography of Mixed Martial Arts, 15:4 Body \& Soc'y 119 (2009)

Tamanaha, Bran Z., Understanding Legal Pluralism: Past to Present, Local to Global, 30 Syndey L. Rev. 375 (2008)

Tushnet, Mark, Popular Constitutionalism as Political Law, 81 Chi.Kent L. Rev. 991 (2006)

Wiltshire, Elaine, Ontario legalizes mixed martial arts, 30:22 Lawyer's Weekly 14 (Oct. 2010)

\section{Secondary Material: Other}

Coalition to Legalize Mixed Martial Arts in New York, http://mmanow.blogspot.ca

United Fighting Championship, Case Study, Global Strategy Group http://globalstrategygroup.com

Unified Rules and other MMA Regulations, Discover UFC, http:// www.ufc.com/discover/sport/rules-and-regulations 
128 DEPAUL J. SPORTS L. \& CONTEMP. PROBS. [Vol. 11:91 